\title{
Blood groups and other polymorphisms in multiple sclerosis
}

\author{
J. L. MacDONALD, D. F. ROBERTS, D. A. SHAW, and M. SAUNDERS \\ Department of Human Genetics, and the Department of Neurology, University of Newcastle upon Tyne
}

Summary. A comparative study was made of blood groups and other polymorphic systems in 136 patients with multiple sclerosis in the Newcastle area. The majority of systems showed no difference from normal frequencies, but differences in the $\mathrm{ABO}$ and rhesus systems are suggested.

The demonstration of an association of multiple sclerosis with the histocompatibility antigens, HL-A 3 of the LA series, and HL-A 7 and W-18 of the FOUR series (Arnason et al, 1972; Naito et al, 1972; Bertrams, Kuwert, and Liedtke, 1972; Jersild et al, 1973; Smeraldi, 1973), has reopened the question of genetic susceptibility to the disease, and in particular whether patients represent a subsection of the population that is genetically identifiable. It appears worth while, therefore, to re-examine the association of the disease with blood groups, which has remained controversial throughout the 10 years since it was first suggested (McAlpine, Lumsden, and Acheson, 1965). This paper reports a comparison of 8 blood group and 5 other polymorphic systems in multiple sclerosis patients in the Newcastle area of the north-east of England.

\section{Subjects and methods}

The subjects were 136 multiple sclerosis patients, diagnosed and accepted as such in the Neurology Department of the Royal Victoria Infirmary, Newcastle. None of the patients was included in the earlier series of Simpson et al (1965) as they had all presented after that date. From each patient a blood and saliva specimen was obtained. The blood specimens were tested by standard serological procedures with the following antisera: anti $A, A_{1}, B, A+B, C, c, D, E, e, M, N, S, s, K, k, P, J k^{a}$, Fy ${ }^{\mathrm{a}}$. The salivas were tested with anti-H lectin and where necessary with $A$ and $B$ antisera for secretor status.

For identification of the various isoenzymes, horizontal starch gel electrophoresis was performed, using gels of 9\% BDH hydrolysed starch. Adenylate kinase was examined by the method of Fildes and Harris (1966), acid

Received 28 January 1975. phosphatase by the discontinuous buffer system as given by Hopkinson, Spencer, and Harris (1964), and phosphoglucomutase was typed using double the molar concentration of all ingredients of the buffer given by Spencer, Hopkinson, and Harris (1964) at pH 7.4. Haptoglobin was typed using the discontinuous buffer system of Poulik and Smithies (1957) at 450 volts for 3 to 4 hours in a cold room at $4^{\circ} \mathrm{C}$, and staining with benzidene to visualize the phenotypes.

Comparative figures were obtained in two ways. The first series (referred to as the population series) is derived from the frequencies regarded as normal for the population. For the $A B O$ and red cell enzyme systems, frequencies specific to the north of England are available (Papiha and Roberts, 1976), and for haptoglobins (Kopeć, 1970; Papiha, 1973). For the other blood groups, however, the MN, Ss, rhesus, Kell, Duffy, Kidd, and secretor frequencies were taken from Race and Sanger (1968, pages 91, 92, 180, 267, 332, 348 , and 294, respectively), and the $P$ frequencies from Mourant (1954, page 366, line 1). Such comparative data are not entirely satisfactory, first because they ignore the possible existence of local genetic variation in the populations of Britain; and secondly because there may be some laboratory variation in technique. Both of these could promote differences between our observed and the 'expected' frequencies. To overcome these two possible objections, as a second control series, specimens were taken from 136 individuals without multiple sclerosis and tested at the same time by the same procedures in this laboratory. These controls included 98 individuals with minimal dermatoses attending the outpatient clinics of the dermatology department, and 38 normal parents of a series of healthy children.

\section{Results}

In Table I are set out the results on the multiple sclerosis patients, compared with the numbers expected in each system from the population 
Blood groups and other polymorphisms in multiple sclerosis

TABLE I

BLOOD GROUPS, RED CELL ISOENZYME, SECRETOR, AND HAPTOGLOBIN TYPES IN MULTIPLE SCLEROSIS

\begin{tabular}{|c|c|c|c|c|c|}
\hline Group & $\begin{array}{l}\text { No. Observed } \\
\text { in MS Patients }\end{array}$ & $\begin{array}{l}\text { No. Expected } \\
\text { From Population } \\
\text { Frequency }\end{array}$ & $\chi^{2}$ & $\begin{array}{l}\text { No. Observed in } \\
\text { Control Sample }\end{array}$ & $x^{2}$ \\
\hline $\begin{array}{l}\mathbf{A} \\
\mathbf{B}+\mathbf{A B}\end{array}$ & $\begin{array}{r}50 \\
9 \\
77 \\
136\end{array}$ & $\begin{array}{l}51.7 \\
17.5 \\
66.8\end{array}$ & 5.75 & $\begin{array}{r}58 \\
20 \\
58 \\
136\end{array}$ & $7.44^{*}$ \\
\hline $\begin{array}{l}\text { CDe/CDe } \\
\text { CDe/cde } \\
\text { cde/cde } \\
\text { cDE/cde } \\
\text { CDe/cDE } \\
\text { cDE/CDE } \\
\text { cDE/cDE } \\
\text { Others }\end{array}$ & $\left.\begin{array}{c}25 \\
32 \\
35 \\
16 \\
14 \\
1 \\
4 \\
-\end{array}\right\}$ & $\begin{array}{r}23.3 \\
43.1 \\
18.5 \\
17.0 \\
18.6 \\
6.4\end{array}$ & $19.10 \ddagger$ & $\begin{array}{r}20 \\
56 \\
20 \\
24 \\
13 \\
3 \\
136\end{array}$ & $12.76 t$ \\
\hline$\underset{\mathrm{N}}{\mathrm{M}}$ & $\begin{array}{r}31 \\
67 \\
38 \\
136\end{array}$ & $\begin{array}{l}38.5 \\
67.2 \\
30.3\end{array}$ & 3.44 & $\begin{array}{r}40 \\
61 \\
35 \\
136\end{array}$ & 1.55 \\
\hline ss & $\begin{array}{r}75 \\
61 \\
136\end{array}$ & $\begin{array}{l}65.7 \\
70.3\end{array}$ & 2.56 & $\begin{array}{r}56 \\
80 \\
136\end{array}$ & $4.77^{*}$ \\
\hline $\begin{array}{l}\mathrm{kk} \\
\mathrm{Kk} \\
\mathrm{KK}\end{array}$ & $\begin{array}{r}123 \\
12 \\
0 \\
135\end{array}$ & $\begin{array}{r}122.9 \\
11.8 \\
0.3\end{array}$ & 0.00 & $\begin{array}{r}126 \\
6 \\
0 \\
132\end{array}$ & 1.37 \\
\hline $\begin{array}{l}\mathbf{P}+ \\
\mathbf{P}-\end{array}$ & $\begin{array}{r}96 \\
37 \\
133\end{array}$ & $\begin{array}{l}98.4 \\
34.6\end{array}$ & 0.23 & 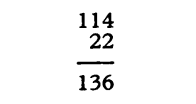 & $4.67^{*}$ \\
\hline $\begin{array}{l}\mathbf{J k}^{\mathbf{a}+} \\
\mathbf{J k}^{\mathbf{a}-}\end{array}$ & $\begin{array}{r}75 \\
28 \\
103\end{array}$ & $\begin{array}{l}77.1 \\
25.9\end{array}$ & 0.22 & $\begin{array}{r}95 \\
33 \\
128\end{array}$ & 0.01 \\
\hline $\begin{array}{l}\mathrm{Fy}^{\mathrm{a}+} \\
\mathrm{Fy}^{\mathrm{a}}-\end{array}$ & $\begin{array}{r}77 \\
32 \\
109\end{array}$ & $\begin{array}{l}72.5 \\
36.5\end{array}$ & 0.83 & $\begin{array}{r}70 \\
39 \\
109\end{array}$ & 0.75 \\
\hline $\begin{array}{l}\mathrm{Se}+ \\
\mathrm{Se}-\end{array}$ & $\begin{array}{l}69 \\
28 \\
97\end{array}$ & $\begin{array}{l}75.0 \\
22.0\end{array}$ & 1.75 & $\begin{array}{l}72 \\
21 \\
93\end{array}$ & 0.69 \\
\hline $\begin{array}{r}\text { Hp } \begin{array}{r}1-1 \\
2-1 \\
2-2\end{array}\end{array}$ & $\begin{array}{r}13 \\
74 \\
49 \\
136\end{array}$ & $\begin{array}{l}20.0 \\
64.3 \\
51.8\end{array}$ & 4.04 & $\begin{array}{r}24 \\
72 \\
40 \\
136\end{array}$ & 4.21 \\
\hline AK ${ }_{2-1}^{1}$ & $\begin{array}{r}97 \\
8 \\
105\end{array}$ & $\begin{array}{r}100.2 \\
4.7\end{array}$ & 2.37 & $\begin{array}{r}121 \\
9 \\
130\end{array}$ & 0.00 \\
\hline $\begin{array}{l}\text { A } \\
\text { BA } \\
\text { B } \\
\text { CB } \\
\text { CA } \\
\text { C }\end{array}$ & $\begin{array}{r}13 \\
39 \\
47 \\
8 \\
2 \\
0 \\
109\end{array}$ & \begin{tabular}{r|}
12.0 \\
44.7 \\
41.5 \\
6.9 \\
3.7 \\
0.3
\end{tabular} & 1.58 & $\begin{array}{r}12 \\
59 \\
48 \\
15 \\
2 \\
0 \\
136\end{array}$ & 3.01 \\
\hline PGM ${ }_{2-1}^{1}$ & $\begin{array}{r}67 \\
43 \\
4 \\
114\end{array}$ & $\begin{array}{r}66.7 \\
41.0 \\
4.3\end{array}$ & 0.12 & $\begin{array}{r}82 \\
34 \\
12 \\
128\end{array}$ & 5.78 \\
\hline
\end{tabular}


comparative series. There are also given the results on the control series, and the values of $\chi^{2}$ and the significance levels in the two sets of comparisons.

First, the observed results are very similar to those expected for the population frequencies and found in the control sample ( Table I) for the MN, Kell, Kidd, and Duffy groups, secretor status, haptoglobin, and the 3 red cell enzyme types, and there are no significant differences in these. For the $\mathrm{ABO}$ blood groups there is an excess of group $O$ individuals over those expected in both comparisons, significant in that against controls. There is a surprise, however, in the striking excess of the cde homozygotes among the patients, highly significant in both comparisons. There is also a suggestion of an excess of the s homozygotes of the MNS system, significant at $5 \%$ against the controls, and a difference in the $\mathbf{P}$ group of low significance, presumably due to a sampling deficit of $P$-individuals in the control series.

The mutual support given by the two control series suggests that there is a real difference in gene frequency in the multiple sclerosis patients by comparison with normals, that this is most pronounced in the rhesus, that it probably also applies to the ABO blood group system, but that there is no difference from normals in $\mathrm{MN}$, Kell, Kidd, Duffy, secretor, haptoglobin, and the 3 isoenzyme frequencies tested. The $\mathrm{P}$ and Ss blood group results may be interpreted as reflecting the vagaries of sampling but from the design of the investigation so far it appears unlikely that these differences are caused by technical procedures. Further work is clearly required to extend the size of sample.

\section{Discussion}

The first suggestion that susceptibility to multiple sclerosis may be associated with the patient's blood group was made in 1965 by McAlpine et al. They drew together data relating to ABO blood groups of 384 patients from various centres in Britain; comparative figures were provided by Dr Kopeć from the records of healthy donors of the National Blood Transfusion Service, and with these the results were compared city by city and overall. The combined data showed a frequency of blood group $O$ among the multiple sclerosis patients, $7.4 \%$ higher than among the controls, the difference being statistically significant $(P=0.0035)$. An earlier study by Alexander et al (1950) noted that the ABO blood group and rhesus negative frequencies in 111 patients in New England 'were in general representative of those prevailing in the general population'. But if Alexander's figures are compared with blood group frequencies in a large number of white Americans, both from New England and from the whole of the United States, as listed in Mourant, Kopeć, and Domaniewska-Sobcak (1958), again there appears an excess of patients with blood group $O$ of $4.9 \%$, though this does not reach significance. Simpson $e t$ al (1965) examined the ABO blood groups of a series of patients in the north-east of England, using strict diagnostic criteria and again making comparison with a large series of healthy blood donors, subdivided into three subsamples to take account of possible regional variations in blood group frequency. There was no significant departure of the observed blood group distribution from that expected from the controls, though in each of the three regional subdivisions and overall there was a slight excess of blood group $\mathrm{O}$, amounting to $1.4 \%$ overall. With the exception of two small subseries included in McAlpine's highly significant results, every series so far examined shows an excess of blood group $\mathbf{O}$ in patients with multiple sclerosis, though the magnitude and statistical significance of the excess varies.

In the second edition of McAlpine et al (1972), the text has been considerably modified, omitting the original data, to indicate an absence of association, and it is this that has prompted us to put on record our present findings. These authors have accepted the criticism of heterogeneity of origin of the data given in their 1965 edition perhaps too readily; for these were compared locality by locality, and the trends are quite consistent for data of this type. Heterogeneity of diagnosis is a different matter, and this one can do nothing about except beware of it. The final paragraph of the new section (page 92) is erroneous, since it implies that 607 families were studied for blood group association, whereas only 78 sib pairs were examined for linkage, and only 23 patients were tested for blood group association! The paper by Simpson et al, the source of the criticism that McAlpine et al accept, itself is subject to criticism. It is not true that, 'the findings of Alexander et al and McAlpine et al, 1965 were contradictory'; on inspection they are mutually supportive. Overall, it seems that the modifications in the 1972 edition of McAlpine $e t$ al are not to be regarded as definitive, and it was obviously of importance to extend this work to further patients about whom the diagnosis is in no doubt, avoiding the criticisms that were made.

If the differences now observed are supported, it may be that the associations are directly causal, in that individuals of blood group $O$, rhesus negative, etc. are intrinsically more likely to develop multiple sclerosis. Alternatively, the associations may be 
indirect; in this case they may perhaps be the result of some stratification in the population, i.e. that there is a stratum of individuals in the population of north-east England characterized by a high frequency of the blood group $\mathrm{O}$ and cde gene and gene combination, and that this stratum is also characterized by susceptibility to multiple sclerosis. It is here that the high frequency of multiple sclerosis in the Orkneys, Shetlands, and northern Scotland may be of relevance in the light of the well-established high frequency of blood group $\mathrm{O}$ in these populations, and studies of the frequencies of genes of other systems, both in affected and normal individuals, in those regions are highly desirable.

Acknowledgment is made to $\mathrm{Mr} \mathrm{C.} \mathrm{K}$. Creen for his technical assistance, to $\mathrm{Dr} \mathrm{K}$. Schapira and $\mathrm{Dr} \mathrm{P}$. Hudgson for practical help and discussions, and to $\mathrm{Dr}$ J. Marks for helping to provide the control specimens; to the Medical Research Council for financial support to initiate this study, and to the Multiple Sclerosis Society of Great Britain for support to bring it to completion.

\section{REFERENCES}

Alexander, L., Loman, J., Lesses, H. F., and Green, I. (1950). Blood groups and multiple sclerosis. Research Publications. Association for Research in Nervous and Mental Disease, 28, 179200.

Arnason, B. G. W., Fuller, T. C., Lerich, J. R., and Winn, H. J. (1972). Leucocyte antigens (HL-A) in multiple sclerosis. In Transplantation Abstracts, Fourth International Congress of the Transplantation Society, San Francisco, September 1972. Ed. by S. L. Kountz. Grune and Stratton, New York.
Bertrams, J., Kuwert, E., and Liedtke, U. (1972). HL-A antigens and multiple sclerosis. Tissue Antigens, 2, 405-408.

Fildes, R. A. and Harris, H. (1966). Genetically determined variation of adenylate kinase in man. Nature, 209, 261-263.

Hopkinson, D. A., Spencer, N., and Harris, H. (1964). Genetical studies on human red cell acid phosphatase. American fournal of Human Genetics, 16, 141-154.

Jersild, C., Sveijgaard, A., Fog, T., and Ammitzbøll, T. (1973). HL-A antigens and disease. I. Multiple sclerosis. Tissue Antigens, 3, 243-250.

Kopeć, A. C. (1970). The Distribution of the Blood Groups in the United Kingdom. Oxford University Press, London.

McAlpine, D., Lumsden, C. E., and Acheson, E. D. (1965). Multiple Sclerosis, a Reappraisal. Churchill Livingstone, Edinburgh and London.

McAlpine, D., Lumsden, C. E., and Acheson, E. D. (1972). Multiple Sclerosis, a Reappraisal, 2nd ed. Churchill Livingstone, Edinburgh and London.

Mourant, A. E. (1954). The Distribution of the Human Blood Groups. Blackwell Scientific Publications, Oxford.

Mourant, A. E., Kopeć, A. C., and Domaniewska-Sobcak, K. (1958). The $A B O$ Blood Groups. Blackwell Scientific Publications, Oxford.

Naito, S., Namerow, N., Mickey, M. R., and Terasaki, P. (1972). I: Multiple sclerosis: association with HL-A3. Tissue Antigens, $3,1-4$.

Papiha, S. S. (1973). Isoenzyme variation in Northumberland. In Genetic Variation in Britain. Ed. by D. F. Roberts and E. Sunderland. Taylor and Francis, London.

Papiha, S. S. and Roberts, D. F. (1976). Haptoglobin distribution in northeast England. Annals of Human Biology. In the press.

Poulik, M. D. and Smithies, O. (1957). Starch gel electrophoresis in discontinuous system of buffer. Nature, 180, 1477.

Race, R. R. and Sanger, R. (1968). Blood Groups in Man, 5th ed. Backwell Scientific Publications, Oxford.

Simpson, C. A., Vejiajiva, A., Caspary, E. A., and Miller, H. (1965). ABO blood groups in multiple sclerosis. Lancet, 1, 1366-1367.

Smeraldi, E. (1973). Immunogenetica della sclerosi multipla. Bollettino dell'Istituto Sieroterapico Milanese, 51, 220-223.

Spencer, H., Hopkinson, D. A., and Harris, H. (1964). Phosphoglucomutase polymorphism in man. Nature, 204, 742-745. 